\title{
Developing Reading Comprehension Modules to Facilitate Reading Comprehension among Malaysian Secondary School ESL Students
}

\author{
Muhammad Javed \\ PhD TESOL Scholar, School of Educational Studies, Universiti Sains Malaysia/ \\ Lecturer, The Islamia University of Bahawalpur, Pakistan, \\ muhammad.javed@iub.edu.pk
}

\section{Lin Siew Eng}

Senior Lecturer, School of Educational Studies, Universiti Sains Malaysia, selin@usm.my

\author{
Abdul Rashid Mohamed \\ Dean School of Educational Studies, Universiti Sains Malaysia, rich@usm.my
}

\begin{abstract}
The study aims to develop a set of 6 Reading Comprehension Modules (RCMs) for Malaysian ESL teachers to facilitate different reading abilities of ESL students effectively. Different skill categories were selected for developing the RCMs. This article describes how and why diverse texts of varying length were adopted and adapted from various authentic sources for ESL students having different reading abilities/bands. It also discusses how literal, reorganisation, and inferential questions were constructed appropriately based on the texts selected in the RCMs. Five experienced content/language experts validated the RCMs while eighty ESL students selected through purposive sampling from a secondary school from Penang, Malaysia participated in the pilot study for determining the reliability of the RCMs. The results of the pilot study revealed that the participants improved their scores gradually. Kuder and Richardson Formula 20 (KR-20) was employed to determine the internal consistency of the RCMs. The calculated values of RCMs ranged between 0.804 and 0.923 that indicate high reliability. The RCMs were standardised through a rigorous developmental process by using the Pebble in the Pond Model (Merril, 2002). We hope that the standardised RCMs would act as indicators for the ESL teachers to enhance ESL students' performance in reading comprehension.
\end{abstract}

Key Words: reading comprehension, comprehension questions, ESL teachers, ESL students, facilitate, RCMs

\section{INTRODUCTION}

Reading comprehension is an interactive process between the reader and the text. During reading process, the reader extracts meaning from the text by utilizing his/her previous knowledge through employing effective reading comprehension strategies 
(Orasanu \& Penney, 1986). Therefore, specific indicators designed to employ effective reading strategies and guidelines can enhance poor readers' performance in reading comprehension (Brown, Armbruster, \& Baker, 1986).

As regards the status of the English language in Malaysia, it is taught as second language in all Malaysia schools in line with the Malaysian Education Act 1966. Therefore, English is given much importance in the Malaysian education system in order to achieve national and international goals (Segawa, 2007). That is why, the Ministry of Education, Malaysia encourages the concerned stakeholders to enhance students' English language skills particularly reading comprehension (Musa, 2003). In the Malaysian context, the Form Four and Form Five Malaysian English Language Syllabus comprises of a major portion of reading comprehension that assists the students to promote various reading skills (Nunan, 2003). The Curriculum Specifications emphasise that curriculum materials must be tailored in line with ESL students' different reading abilities and needs (Thang \& Kumarasamy, 2006).

As regards the teaching of the English language, reading is the most important skill amongst others (Gu, 2003). A lot of efforts had been made to enrich ESL students' reading comprehension, however, the students still need to be more proficient in comprehending the text (Afflerbach, Pearson, \& Paris, 2008). In connection with enhancing the students' reading competency, the selected reading textual material with local contexts is helpful for ESL teachers to enhance their reading comprehension abilities (Paulston \& Bruder, 1976). Moreover, the comprehension questions should also be constructed in line with reading skill categories (Nuttall, 2005).

\section{STATEMENT OF THE PROBLEM}

The ESL teachers lack of suitable reading materials to facilitate ESL students with different reading abilities to enhance their reading comprehension (David \& Govindasamy 2006). Hassan and Selamat, (2002) identified that, in Malaysia, the ESL teachers have to sort out material from other sources such as internet and newspapers because the textbooks are either too difficult or too easy and do not match to the abilities of different students. Generally, the teachers face difficulties regarding the selection of reading material to develop students' reading ability. Most previous studies indicate that the ESL teachers need to use a variety of reading modules for teaching reading academic texts at all levels, especially at school levels in Malaysia (Blachowicz, Blachowicz, \& Ogle, 2008). Nambiar (2007) stated that the teaching of reading in Malaysian schools does not often focus on all types of reading comprehension skill categories.

There is little work done regarding developing modules for ESL teachers to teach reading comprehension at school level in Malaysia. This is one of the challenging issues for ESL teachers that they are facing the lack of standardised RCMs and appropriate guidelines for teaching reading comprehension (Ortega, 2009). O'Reilly, Sinclair and McNamara (2004) also reported that most of the ESL teachers merely teach with the help of the textbooks provided by the Ministry of Education Malaysia and even from workbooks. Furthermore, some teachers are not well aware whether the comprehension questions they formulate can test students' reading ability (Day \& Bamford, 2005). In view of the discussion stated, the present study aims to develop standardised RCMs to 
enrich ESL students' reading comprehension at school level in Malaysia according to their reading abilities.

\section{REVIEW OF LITERATURE \\ Reading and Reading Comprehension}

Reading is a complex cognitive process in which a reader decodes the symbols or printed messages into sounds (Grabe \& Stoller, 2002), while, reading comprehension is a vigorous process of constructing meaning from a piece of text and understanding it effusively and comprehensively (Nakamoto, Lindsey, \& Manis, 2008). With regard to the teaching of reading comprehension, a dynamic, vibrant, and vigorous process of teaching reading comprehension by involving reading materials for constructing meanings from the text assists ESL teachers to enhance ESL students' academic performance (Anderson, 2003).

As far the reading portion in textbooks is concerned, it comprises of a story, an essay, or an argument followed by some comprehension questions in order to develop ESL students' reading comprehension. In the contexts of reading comprehension, Barrett's taxonomy of reading comprehension (cited in Clymer, 1968) presented five skill categories of reading comprehension such as 1) literal, 2) reorganisation, 3) inferential, 4) evaluation, and 5) appreciation. In addition, Day and Park's (2005) taxonomy of reading comprehension, and Bloom's taxonomy of educational objectives revised by Anderson et al. (2001) presented almost the similar skill categories. According to the taxonomies, literal comprehension refers to the information explicitly stated in the text, whereas reorganisation comprehension needs an ability to synthesise, analyse, and integrate the information plainly stated in the text. Contrarily, inferential comprehension refers to locate information implicitly stated in the text through making assumptions and conjectures. These three skill categories are similar in the taxonomies in terms of concepts and meanings and are commonly used terms in the area of reading comprehension (Gill, 2008).

In view of the above discussion, the three skills stated in the afore-mentioned taxonomies were taken into consideration for developing the RCMs for ESL teachers to facilitate reading abilities among ESL students of Form 1 to Form 5 since they are helpful for selecting texts and constructing comprehension questions. Furthermore, these three skills are appropriate to teach language skills whereas the rest of the skills are helpful for teaching the English language (Nuttall, 2005).

\section{Reading Modules Developed by others}

Pearson and Gallagher (1983) stated that specific modules developed for reading comprehension play an effective role not only for ESL teachers to teach reading comprehension effectively but also for ESL students to enhance their reading ability and understanding. In connection with the reading modules, currently, there is a limited number of reading modules available for ESL teachers to teach reading comprehension. For example, Brunk-Chavez (2008) developed a set of 14 instructional modules for college level teachers to provide effective reading strategies and guidelines to teach reading comprehension to ESL students. Virginia Department of Education, United 
States of America (2008) also developed reading modules namely 'Middle School Reading Modules' for reading comprehension. Similarly, Ministry of Education, New Zealand also developed 5 different modules for developing students' reading comprehension (Ministry of Education New Zealand, 2007). These modules are effective for teaching the English language reading skills. However, they are rather general, rigid, and broad or associated with particular level or contexts that provide general guidelines for ESL teachers. Therefore, the researchers attempted to develop the RCMs for ESL Malaysian teachers to provide comprehensive guidelines and effective reading strategies to teach reading comprehension to ESL students.

\section{Research Objective}

The key objective of the study is to develop a set of 6 RCMs for ESL teachers to facilitate ESL students' reading comprehension abilities at secondary school level in Malaysia.

\section{Research Questions}

Following research questions are designed to achieve the objective of the study.

RQ1: What type of reading comprehension texts should be selected for the different levels of reading ability (Band 1- Band 6)?

RQ2: What type of reading comprehension questions should be constructed to develop the different sub-skills of reading comprehension to answer the literal, reorganisation and inferential comprehension questions?

RQ3: What is the content validity and reliability of the prototype RCMs?

\section{METHOD}

The researchers took many steps to design and develop RCMs. Initially, after a profound and deliberate study, the researchers selected the Pebble in the Pond Model (see figure 1) for developing RCMs since it is remarkable and significant model in the field of designing materials (Merrill, 2002).

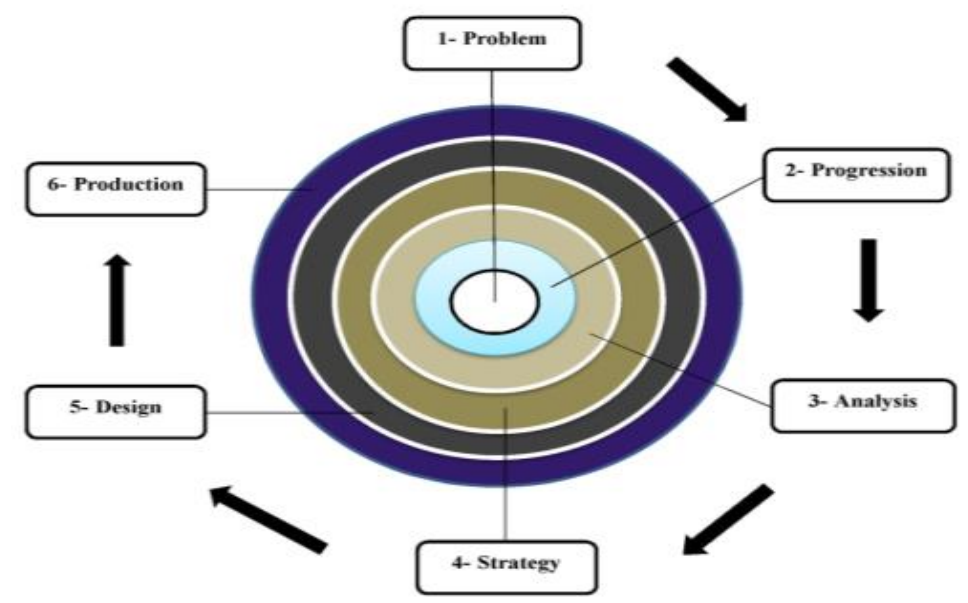

Figure 1: The Pebble in the Pond Model (Merril, 2002) 
This model consists of six different phases namely, problem, progression, analysis, strategy, design, and production (Merrill, 2002). The researchers systematically developed the RCMs in line with the six phases of this model. In order to develop a set of 6 RCMs, the Descriptors of Reading Ability developed by Abdul Rashid Mohamed, Lin, and Shaik Abdul Malik (2010), the Malaysian English Language Syllabus, Barrett's taxonomy of reading comprehension (1968), Day and Park's (2005) taxonomy of reading comprehension, and Bloom's taxonomy of educational objectives revised by Anderson et al. (2001) were taken into consideration. The procedure for developing the RCMs is elucidated in detail below.

\section{Descriptors of Reading Ability}

First of all, the researchers adopted the 'Descriptors of Reading Ability' developed by Abdul Rashid et al. (2010). The 'Descriptors of Reading Ability' are useful for developing RCMs since they are developed based on the reading abilities of students to answer literal, reorganisation, and inferential comprehension questions. These descriptors explain what an ESL student can do or cannot do.

\section{Malaysian English Language Syllabus}

The Malaysian English Language Syllabus specifies the contents for students to enhance their language proficiency. It comprises of specific portion for developing the students' reading comprehension. It assists the students to become independent and efficient readers in order to comprehend the text appropriately (Ministry of Education Malaysia, 2011). The skill specifications stated in the Malaysian English Language Syllabus are ideal to develop ESL students' reading comprehension. However, they neither enable the teachers to know the students' level of reading comprehension nor do they reflect any diagnostic purpose (Sheikh-Ahmad, 1997). As regards the objective of the present study, the skill specifications stated in the Malaysia English Language Syllabus were used in this study for developing the RCMs.

\section{Barrett's Taxonomy of Reading Comprehension}

The Barrett's taxonomy of reading comprehension (cited in Clymer, 1968), comprises of five major skill categories of reading comprehension such as literal, reorganisation, inferential, evaluation, and appreciation that are categorised from easy to difficult level (Alderson \& Urquhart, 1984). All the skill categories are significant, however only first three skill categories such as literal, reorganisation, and inferential comprehension were considered for developing the RCMs.

\section{Day and Park's Taxonomy of Reading Comprehension}

Day and Park (2005) also presented a reading comprehension taxonomy that is similar to Barrett's taxonomy of reading comprehension. It consists of six types of comprehension along with five forms of questions (refer to Table 1).

Table 1: Day and Park's (2005) taxonomy of reading comprehension for developing and evaluating reading comprehension questions (adopted with written permission)

Forms of Six Types of Comprehension




\begin{tabular}{|c|c|c|c|c|c|c|}
\hline Questions & $\begin{array}{c}\text { Literal } \\
\text { Comprehension }\end{array}$ & Reorganisation & Inference & Prediction & Evaluation & $\begin{array}{l}\text { Personal } \\
\text { Response }\end{array}$ \\
\hline Multiple Choice & $\times$ & $x$ & $x$ & & & \\
\hline $\begin{array}{l}\text { Who/When/What// } \\
\text { Where/ How/why }\end{array}$ & $\times$ & $x$ & $x$ & & & \\
\hline \multicolumn{7}{|l|}{ Alternative } \\
\hline True/False & & & & & & \\
\hline Yes/No & & & & & & \\
\hline
\end{tabular}

All the skill categories of this taxonomy are valuable for ESL teachers to construct their own comprehension questions to enhance ESL students' reading comprehension. However, as regards the objective of the study, only first three types of comprehension along with first two forms of questions were considered for developing the RCMs since the current study focused on the teaching of the English language.

\section{Revised Bloom's Taxonomy of Educational Objectives}

Bloom's taxonomy of educational objectives revised by Anderson et al. (2001) is also helpful for ESL teachers for designing curricula, instructional materials and tests. It consists of six levels of cognitive functioning. However, the selected skill categories such as remembering (literal), understanding (reorganisation), and analysing and creating (inferential) were consideration to develop the RCMs.

\section{Reading Comprehension Strategies}

According to Afflerbach at al. (2008), reading strategies help the readers to decode text, understand the words, and construct or derive meanings of the text. Lapp, Flood, Brock, and Fisher (2013) concluded that well developed cognitive strategies have been used in various research studies since ESL students need to reread, interpret, ponder, integrate, analyse, infer, critique, connect, review and evaluate the ideas during reading the text in order to answer comprehension questions. Therefore, various reading strategies were recommended in the RCMs.

As for the development of the RCMs is concerned, different skill categories taken from Descriptors of Reading Ability, the Malaysian English syllabus, and three taxonomies of reading comprehension stated above are elaborated in Table 2.

Table 2: Summary of reading skill categories selected for developing the RCMs

\begin{tabular}{|c|c|c|c|c|}
\hline $\begin{array}{c}\text { Descriptors of } \\
\text { Reading Ability } \\
\text { adopted from } \\
\text { Abdul Rashid et } \\
\text { al. (2010) }\end{array}$ & $\begin{array}{c}\text { Skill Specifications } \\
\text { in the Malaysian } \\
\text { English Language } \\
\text { Syllabus }\end{array}$ & $\begin{array}{c}\text { Barrett's } \\
\text { Taxonomy } \\
\text { of Reading } \\
\text { Comprehension } \\
\text { (1968) }\end{array}$ & $\begin{array}{c}\text { Day's \& Park's } \\
\text { Taxonomy of } \\
\text { Reading } \\
\text { Comprehension } \\
\text { (2005) }\end{array}$ & $\begin{array}{c}\text { Revised Bloom's } \\
\text { Taxonomy of } \\
\text { Educational } \\
\text { Objectives (2001) }\end{array}$ \\
\hline $\begin{array}{l}\text { Literal } \\
\text { Comprehension } \\
\text { i. Identifying } \\
\text { supporting } \\
\text { details in the } \\
\text { text } \\
\text { ii. Identifying } \\
\text { main ideas in }\end{array}$ & $\begin{array}{l}\text { Literal } \\
\text { Comprehension } \\
\text { i. Scanning for } \\
\quad \text { certain details } \\
\text { ii. Identifying } \\
\quad \text { main ideas in a } \\
\text { simple text } \\
\text { iii. Identifying }\end{array}$ & $\begin{array}{l}\text { Literal } \\
\text { Comprehension } \\
\text { i. Identifying } \\
\text { supporting } \\
\text { details in the } \\
\text { text } \\
\text { ii. Identifying } \\
\text { main ideas in }\end{array}$ & $\begin{array}{l}\text { Literal } \\
\text { i. Understanding of } \\
\text { the straightforward } \\
\text { meaning of the text } \\
\text { ii. Locating the } \\
\text { answers of literal } \\
\text { comprehension } \\
\text { questions directly }\end{array}$ & $\begin{array}{l}\text { Remembering } \\
\text { (literal) } \\
\text { i. Identifying } \\
\text { letters, phrases, } \\
\text { sentences, and } \\
\text { supporting } \\
\text { details } \\
\text { ii. Identifying main }\end{array}$ \\
\hline
\end{tabular}




\begin{tabular}{|c|c|c|c|c|}
\hline the text & $\begin{array}{l}\text { supporting details in } \\
\text { a simple text }\end{array}$ & the text & stated in the text & idea \\
\hline $\begin{array}{l}\text { Reorganisation } \\
\text { i. Extracting } \\
\text { supporting } \\
\text { details } \\
\text { ii. Acquiring the } \\
\text { meaning of } \\
\text { words by using } \\
\text { contextual } \\
\text { clues } \\
\text { iii. Identifying } \\
\text { simple cause } \\
\text { and effect }\end{array}$ & $\begin{array}{l}\text { Reorganisation } \\
\text { i. Extracting } \\
\text { supporting details } \\
\text { ii. Acquiring the } \\
\text { meaning of words } \\
\text { by understanding } \\
\text { contextual clues } \\
\text { iii. Identifying } \\
\text { simple cause and } \\
\text { effect }\end{array}$ & $\begin{array}{l}\text { Reorganisation } \\
\text { i. Extracting } \\
\text { supporting } \\
\text { details } \\
\text { ii. Acquiring the } \\
\text { meaning of } \\
\text { words by } \\
\text { using } \\
\text { contextual } \\
\text { clues } \\
\text { iii. Identifying } \\
\text { simple cause } \\
\text { and effect }\end{array}$ & $\begin{array}{l}\text { Reorganization } \\
\text { i. Using information } \\
\text { from various parts } \\
\text { of the text and } \\
\text { combining them } \\
\text { for additional } \\
\text { understanding } \\
\text { ii. Finding out the } \\
\text { relatively explicit } \\
\text { information } \\
\text { from the text }\end{array}$ & $\begin{array}{l}\text { Understanding } \\
\text { (reorganisation) } \\
\text { i. Translating } \\
\text { ideas or } \\
\text { information } \\
\text { explicitly } \\
\text { stated } \\
\text { ii. finding cause } \\
\text { and effect } \\
\text { relationships }\end{array}$ \\
\hline $\begin{array}{l}\text { Inferential } \\
\text { Comprehension } \\
\text { i. Drawing } \\
\text { conclusions } \\
\text { ii. Making } \\
\text { inferences }\end{array}$ & $\begin{array}{l}\text { Inferential } \\
\text { Comprehension } \\
\text { i. Drawing } \\
\text { conclusions in } \\
\text { simple texts } \\
\text { ii. Making } \\
\text { inferences }\end{array}$ & $\begin{array}{l}\text { Inferential } \\
\text { Comprehension } \\
\text { i. Drawing } \\
\quad \text { conclusions } \\
\text { ii. Making } \\
\text { inferences }\end{array}$ & $\begin{array}{l}\text { Inference } \\
\text { i. Finding out } \\
\text { information based } \\
\text { on material that is } \\
\text { in the text, but not } \\
\text { explicitly stated } \\
\text { ii. Understanding of } \\
\text { the text with their } \\
\text { own knowledge } \\
\text { and intuitions }\end{array}$ & $\begin{array}{l}\text { Analysisng and } \\
\text { creating } \\
\text { (inferential) } \\
\text { i. Understanding } \\
\text { one's } \\
\text { experiences } \\
\text { how they relate } \\
\text { to text inferring } \\
\text { details and main } \\
\text { ideas }\end{array}$ \\
\hline
\end{tabular}

\section{TYPES OF TEXTS SELECTED FOR RCMS}

The researchers selected/adapted diverse textual materials from various sources in order to answer the following research question:

Research Question 1: What type of reading comprehension texts should be selected for the different levels of reading ability (Band 1- Band 6)?

Therefore, in compliance with the Research Question 1, the researchers accessed and consulted various sources such as magazines, workbooks, newspapers, periodicals, and authentic websites to select/adapt diverse texts for the RCMs. With regard to the structure of developing the RCMs, basically, a set of 6 RCMs was designed and developed. The RCMs were divided into three levels with varying length of text. The difficulty level and the length of the text for each band was set in line with the Descriptors of Reading Ability adopted from Abdul Rashid et al. (2010). Furthermore, the difficulty level of all the texts was determined by using The Flesch Reading Ease Readability Formula developed by Rudolph Flesch in 1948 (Spache (1953). The structure of each Reading Comprehension Module (RCM) is stated in Table 3.

Table 3: The structure of the RCMs

\begin{tabular}{|c|c|c|c|c|}
\hline $\begin{array}{l}R C M \text { and } \\
\text { Band }\end{array}$ & Part/Skill categories & $\begin{array}{c}\text { Number } \\
\text { of text }\end{array}$ & $\begin{array}{c}\text { Length of } \\
\text { text }\end{array}$ & Level \\
\hline \multirow{3}{*}{$\begin{array}{l}\text { RCM } 1 \\
\text { Band } 1\end{array}$} & Part A: Literal Comprehension & 3 & \multirow{3}{*}{$\begin{array}{l}100-150 \\
\text { (words) }\end{array}$} & \multirow{3}{*}{ Elementary } \\
\hline & Part B: Reorganisation Comprehension & 3 & & \\
\hline & Part C: Inferential Comprehension & 3 & & \\
\hline RCM 2 & Part A: Literal Comprehension & 3 & $100-150$ & Elementary \\
\hline
\end{tabular}




\begin{tabular}{|c|c|c|c|c|}
\hline \multirow[t]{2}{*}{ Band 2} & Part B: Reorganisation Comprehension & 3 & \multicolumn{2}{|l|}{ (words) } \\
\hline & Part C: Inferential Comprehension & 3 & & \\
\hline \multirow{3}{*}{$\begin{array}{l}\text { RCM } 3 \\
\text { Band } 3\end{array}$} & Part A: Literal Comprehension & 3 & \multirow{3}{*}{$\begin{array}{l}150-250 \\
\text { (words) }\end{array}$} & \multirow{3}{*}{ Intermediate } \\
\hline & Part B: Reorganisation Comprehension & 3 & & \\
\hline & Part C: Inferential Comprehension & 3 & & \\
\hline \multirow{3}{*}{$\begin{array}{l}\text { RCM } 4 \\
\text { Band } 4\end{array}$} & Part A: Literal Comprehension & 3 & \multirow{3}{*}{$\begin{array}{l}300-400 \\
\text { (words) }\end{array}$} & \multirow{3}{*}{ Intermediate } \\
\hline & Part B: Reorganisation Comprehension & 3 & & \\
\hline & Part C: Inferential Comprehension & 3 & & \\
\hline \multirow{3}{*}{$\begin{array}{l}\text { RCM } 5 \\
\text { Band } 5\end{array}$} & Part A: Literal Comprehension & 3 & \multirow{3}{*}{$\begin{array}{c}400-600 \\
\text { (words) }\end{array}$} & \multirow{3}{*}{ Advanced } \\
\hline & Part B: Reorganisation Comprehension & 3 & & \\
\hline & Part C: Inferential Comprehension & 3 & & \\
\hline \multirow{3}{*}{$\begin{array}{l}\text { RCM } 6 \\
\text { Band } 6\end{array}$} & Part A: Literal Comprehension & 3 & \multirow{3}{*}{$\begin{array}{c}600-750 \\
\text { (words) }\end{array}$} & \multirow{3}{*}{ Advanced } \\
\hline & Part B: Reorganisation Comprehension & 3 & & \\
\hline & Part C: Inferential Comprehension & 3 & & \\
\hline
\end{tabular}

In order to answer the research question 1, the researchers selected various literal, reorganisation, and inferential comprehension texts from various authentic sources in connection with the reading abilities of ESL students in each band. Therefore, a set of 6 RCMs was developed in order to facilitate all ESL students having different reading abilities. Various forms of text were included in each RCM in line with different themes such as people, environment, social issue, health, and science and technology as stated in the Malaysian English Language Syllabus. Similarly, various genres of texts such as advertisements, letters, speeches, emails, essays, newspaper reports, and dialogues were added in each RCM. The basic purpose behind the selection of various genres was to construct versatile comprehension questions. In addition, the length and difficulty level of the texts for each RCM increased gradually from RCM 1 band 1 to RCM 6 band 6 . Furthermore, suitable visual images relevant to the textual materials were added since they might be helpful for ESL teachers and students to comprehend the text (Robberecht, 2007). Besides stating the total number of words under each text, the source of the text was also cited appropriately at the end of each text. Furthermore, following points were also kept in mind during the selection of the texts for each RCM.

a. The difficulty level of the texts was set keeping in mind the reading abilities of ESL students in each band in line with the Descriptors of Reading Ability.

b. The texts were included with reference to a variety of the Malaysian contexts.

c. Reading sub-skills were mentioned in each passage throughout each RCM.

d. Each sub-skill was stated against each comprehension question as well.

e. Four plausible distractors were given under each comprehension question.

f. The language of the texts and the comprehension questions were made intelligible.

g. The guidelines were given under each text for ESL teachers and students to answer all types of comprehension questions by using different reading strategies.

After the selection of comprehension texts for RCMs, the researchers constructed comprehension questions to answer the research question 2 as stated below:

Research Question 2: What type of reading comprehension questions should be constructed for the literal, reorganisation, and inferential comprehension questions? 


\section{TYPES OF READING COMPREHENSION QUESTIONS}

After selecting texts for the RCMs, comprehension questions were constructed very carefully under each text. Thus, 15 comprehension questions were constructed under each Part of the RCM. In addition, the selected sub-skills were focused while constructing comprehension questions in each part of the RCM. For instance, two reading sub-skills such as identifying supporting detail and locating main idea were considered in Part A. Three reading sub-skills such as extracting supporting detail, acquiring the meaning of words by using contextual clues and identifying simple cause and effect were focused in Part B, whereas two reading sub-skills such as making inferences and drawing conclusion were considered in Part C. In addition, all the comprehension questions were indicated as signposts questions throughout the RCMs since Nuttal (2005) elucidated with logical reasoning that the signpost questions are helpful for readers to answer the required questions from the text. The researchers also recommended some affective reading strategies that might assist ESL teachers to answer comprehension question. Moreover, one mark was allocated for each comprehension question. Therefore, each part of a RCM comprises of 15 marks and each RCM consists of 45 marks totaling 270 marks for all RCMs.

After selecting the texts and constructing comprehension questions, the researchers tested the validity and reliability of the RCMs to answer the following research question. Research Question 3: What is the content validity and reliability of the prototype RCMs?

\section{VALIDITY AND RELIABILITY OF THE RCMS}

After developing the prototype RCMs, the researchers conducted a pilot study to test the content validity and reliability of the RCMs. As regards the content validity of the prototype RCMs, it was determined through a systematic process. Five content experts examined the prototype RCMs in order to test their content validity. Two content experts were TESOL university teachers, whereas; three were experienced examiners of the English Language papers of Malaysian Certificate of Education, Lower Secondary Assessment, and Primary School Examination Test. The content experts checked the suitability and appropriateness of the texts and the comprehension questions to determine the content validity of the RCMs. The content experts indicated some problems with regard to a) the type of the texts, b) the types of reading comprehension questions, c) correction of spelling and grammatical errors, d) consistency in the space between sentences and paragraphs, and e) the length of distractors. After receiving the feedback provided by the content experts, the required changes were incorporated to modify and refine in the prototype RCMs as follows:

\section{Types of Texts}

The experts pointed out some of the texts that were not familiar to the Malaysia students' cultural and social contexts. Therefore, the experts suggested the researchers to replace such texts with those that are in line with the Malaysian contexts. Likewise, some of the texts were not suitable with regard to the level of difficulty and length of the texts. They were either too short, too long, too difficult or too easy for a particular level/band of students. Thus, the experts suggested the researchers to change such texts 
too. Similarly, some of the graphs were used instead of the textual materials; therefore, the experts proposed the researchers to use textual materials instead of the graphs since the present study aims to focus on reading comprehension based on the textual materials. Finally, the researchers incorporated the changes accordingly based on the constructive comments given by the experts.

\section{Types of Reading Comprehension Questions}

The experts pointed out that some of the comprehension questions were not constructed appropriately in line with the selected skill categories. For instance, some of the comprehension questions were neither literal nor inferential in their true sense. Some of the comprehension questions were also not apprehensible and understandable. Therefore, the experts suggested the researchers to construct suitable, relevant, and comprehensible questions in line with each skill category. Thus, the researchers made changes to construct appropriate comprehension questions as suggested by the experts.

\section{Correction of Spelling and Grammatical Errors}

The language experts highlighted some spelling and substantial grammatical errors in the textual materials and comprehension questions. Therefore, the researchers removed the spelling and grammatical errors in the light of the experts' recommendations.

\section{Consistency in the Space between Sentences and Paragraphs}

The experts drew the attention of the researchers to the inconsistency between the spacing of the sentences and paragraphs. Therefore, consistency and uniformity were made as directed by the experts to increase the rate of readability and understanding.

\section{Length of the Distractors}

The experts also pointed out the length of the distractors that was not equal. In connection with the length of distractors, Haladyna, Downing, and Rodriguez (2002) stated that it is generally observed that longer or the shorter distractor is commonly considered the correct answer without any logical ground. Therefore, the researchers tried their best to make all the distractors equal in length.

After checking the content validity, the reliability of the prototype RCMs was determined. As regards the matter of determining the reliability, RCM 2 band 2, RCM 3 band 3, RCM 4 band 4, and RCM 5 band 5 were used in order to conduct a pilot study. Eighty ESL students of Form Four were selected through purposive sampling from a selected secondary school in Penang Malaysia. Before applying the prototype RCMs, the reading comprehension test developed by Abdul Rashid et al. (2010) was used in order to determine the students' reading ability. The scores/bands based on the pilot study are presented in Table 4.

Table 4: Results of the pilot study to determine the ESL students' reading ability/band

\begin{tabular}{ccc}
\hline Bands & Raw scores for each Band & Number of Students for Each Band $(N=80)$ \\
\hline 1 & $00-06$ & 00 \\
\hline 2 & $07-18$ & 18 \\
\hline 3 & $19-29$ & 26 \\
\hline 4 & $30-41$ & 19 \\
\hline 5 & $42-53$ & 17 \\
\hline 6 & $54-60$ & 00 \\
\hline
\end{tabular}


According to Table 4, the ESL students' scores represent that they fall only in band 2, band 3, band 4, and band 5. Contrarily, none of the ESL students got band 1 or band 6 . Therefore, RCMs 2 to RCM 5 were employed to conduct the pilot study to the students who attained band 2 to band 5 respectively. The pilot study of the prototype RCMs was conducted through different stages during twenty-four working days. Text 1 of each Part of each RCM was taught by using reading strategies proposed in the RCMs and text 2 and text 3 of each part of each RCM were given to the participants as tests to test their level of comprehension. After teaching the selected texts, KR-20 was used to determine the reliability of each skill category of the prototype RCMs. The calculated reliability values are stated in Table 5.

Table 5: Reliability of the prototype RCMs

\begin{tabular}{lllc}
\hline Module/Band & Part & Sub-skill & Reliability values \\
\multirow{2}{*}{ Prototype RCM 2 } & Part A & Literal Comprehension & 0.804 \\
Band 2 & Part B & Reorganisation Comprehension & 0.808 \\
& Part C & Inferential Comprehension & 0.853 \\
\hline \multirow{2}{*}{ Prototype RCM 3 } & Part A & Literal Comprehension & 0.892 \\
Band 3 & Part B & Reorganisation Comprehension & 0.873 \\
& Part C & Inferential Comprehension & 0.824 \\
\hline \multirow{2}{*}{ Prototype RCM 4 } & Part A & Literal Comprehension & 0.903 \\
Band 4 & Part B & Reorganisation Comprehension & 0.914 \\
& Part C & Inferential Comprehension & 0.892 \\
\multirow{2}{*}{ Prototype RCM 5 } & Part A & Literal Comprehension & 0.869 \\
Band 5 & Part B & Reorganisation Comprehension & 0.923 \\
\hline
\end{tabular}

Table 5 reveals that all the calculated values indicate high reliability. A consolidated comparison of the ESL students' scores in RCM 2 to RCM 5 is made in Figure 2.

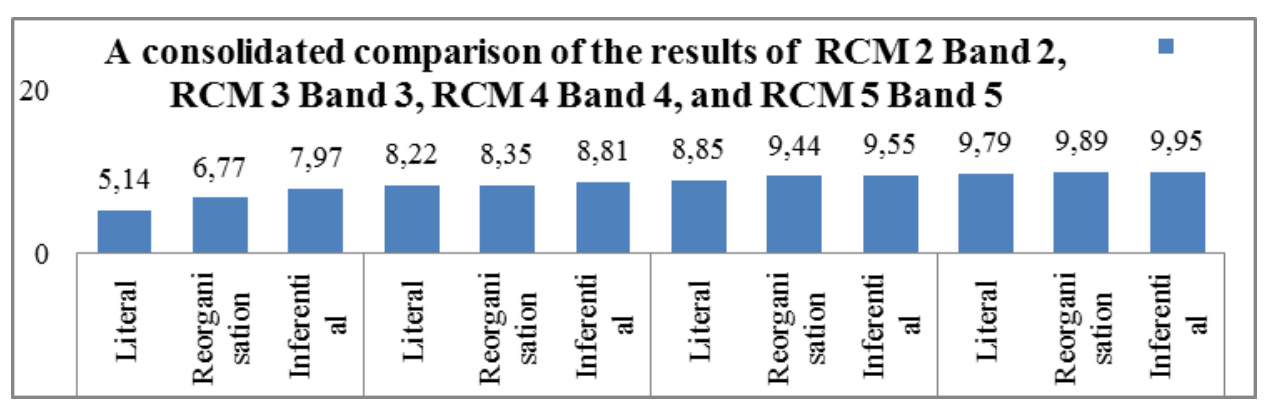

Figure 2: Comparisons of participants' scores in RCM 2 band 2 to RCM 5 band 5

Figure 2 indicates that the ESL participants improved their scores in each skill category in each RCM. The researchers also observed that the reading strategies particularly signpost questions assisted the students to answer the literal, reorganisation, and inferential comprehension questions. Therefore, it can be concluded that the RCMs are helpful for ESL students to improve their reading comprehension.

In connection with the results of pilot study, the researchers noticed that some of the 
texts were comparatively difficult. Therefore, some changes were made in the texts accordingly and a few of the texts were replaced with the easier texts in line with the students' reading abilities in order to develop standardised RCMs. Finally, after making the necessary changes, the researchers developed standardised RCMs, which contain various stages such as introduction, general and pacific objectives, previous knowledge text, presentation, guidelines for ESL teachers, practice, and production.

\section{DISCUSSION AND CONCLUSION}

Basically, this research aimed to assist the ESL teachers in Malaysia to teach reading comprehension at secondary school level. It is significant since a little research has been done before for developing RCMs for ESL Malaysian secondary school teachers to teach students how to answer literal, reorganisation, and inferential comprehension questions according to the students' reading abilities. The standardised RCMs will act as indicators for the ESL teachers to teach sub-skills of reading comprehension at easy, intermediate and advanced levels. These modules will help the ESL teachers to transfer their knowledge to the students effectively with better methodology by employing various effective reading strategies. According to Pawanchik (2006) and Jalleh (2012), two-third of the Malaysian teachers did not meet the proficiency level to teach the ESL students effectively at school level. Therefore, the RCMs will help the ESL teachers improve ESL students' exposure in teaching reading comprehension at school level in Malaysia. Finally, the standardised RCMs developed by the researchers will support ESL teachers to improve ESL students' reading comprehension since they are adaptable, flexible, and user-friendly with a tremendous potential to use at national level to achieve the goals set in the Malaysian English Language Syllabus.

\section{IMPLICATIONS OF THE STUDY}

It is hoped that the standardised RCMs developed by the researchers would assist the ESL teachers to apply at secondary school level for teaching reading comprehension skills to ESL students. Various reading strategies proposed in the standardised RCMs will also help the ESL teachers to enrich their pedagogical skills, teaching approaches, and professional development. The RCMs, in return, will result in improving ESL students' reading comprehension, learning development, and academic achievement as well. It is also expected that program level administrators, teacher trainers, professional developers, and the state will benefit the standardised RCMs since the researchers, after analysing various aspects, made tireless and strenuous efforts for designing and developing the RCMs through a systematic and coherent process in order to enhance ESL students' academic achievement in reading comprehension. Finally, the standardised RCMs can be handed over to the District Education Officers and the State Education Offices in Malaysia as well. They can recommend the RCMs to the ESL teachers to apply in the classroom for teaching reading comprehension. If all the ESL teachers consider that the RCMs are beneficial, then, a comprehensive report can be sent to the Ministry of Education, Malaysia. The Ministry, as a response, could benefit the RCMs to add the relevant contents in the syllabi in order to improve ESL students' reading comprehension. 


\section{FUTURE PLAN}

Each standardised RCM consists of 45 to 50 pages; therefore, it is hard to enclose all the RCMs here with this article. In our opinion, these modules have a tremendous and remarkable potential for ESL teachers to teach reading comprehension skills. Therefore, our future plan is to upload these modules to our online forum in near future, so that the readers may benefit this useful product.

\section{ACKNOWLEDGEMENTS}

We would like to show our gratitude to the content/language experts and the principal of the selected school who assisted for testing the validity and reliability of the RCMs.

\section{REFERENCES}

Abdul Rashid Mohamed., Lin, S. E., \& Shaik Abdul Malik, I. (2010). Making sense of reading scores with reading evaluation and decoding system (READS). English Language Teaching, 3(3), 35-46.

Afflerbach, P., Pearson, P. D., \& Paris, S. G. (2008). Clarifying differences between reading skills and reading strategies. The Reading Teacher, 61(5), 364-373.

Alderson, J. C., \& Urquhart, A. H. (1984). Reading in a foreign language. London: Longman.

Anderson, L. W., Krathwohl, D. R., Airasian, P. W., Cruikshank, K. A., Mayer, R. E., Pintrich, P. R., ... \& Wittrock, M. C. (2001). A taxonomy for learning, teaching, and assessing: A revision of Bloom's taxonomy of educational objectives, abridged edition. White Plains, NY: Longman.

Anderson, N. J. (2003). Scrolling, clicking, and reading English: Online reading strategies in a second/foreign language. The Reading Matrix, 3(3), 1-33.

Barrett, T. C. (1968). What is reading? Some current concepts. In H. M. Robinson (Ed.) Innovation and change in reading instruction: The sixteenth handbook of the National Society for the Study of Education. Chicago: The University of Chicago Press.

Blachowicz, C. L. Z., Blachowicz, C., \& Ogle, D. (2008). Reading comprehension: Strategies for independent learners: New York, NY: The Guilford Press.

Brown, A. L., Armbruster, B. B., \& Baker, L. (1986). The role of metacognition in reading and studying. Reading Comprehension: From Research To Practice, 49-75.

Brunk-Chavez, B. L. (2008). Professional Development Modules Project: Reading Comprehension. The University of Texas at El Paso. Retrieved http://reading.utep.edu/modules.html

Clymer, T. (1968). What is reading?: Some current concepts. $67^{\text {th }}$ Yearbook of National Society for the Study of Education, 7-29.

David, M. K., \& Govindasamy, S. (2006). National identity and globalization in Malaysia. In Tsui, A. B. M., \& J. W. Tollefson (Eds.), Language Policy, Culture, and identity in Asian Contexts, (pp. 55-72). Mahwah, NJ: Lawrence Erlbaum.

Day, R., \& Bamford J. (2005). Reaching Reluctant Readers. English Teaching Forum, 38(3). Retrieved from http://eca.state.gov/forum/vols/vol38/no3/p12.htm. 
Day, R. R., \& Park, J. (2005). Developing reading comprehension questions. Reading in a Foreign Language, 17(1), 60-73.

Gill, S. R. (2008). The comprehension matrix: A tool for designing comprehension instruction. The Reading Teacher, 62(2), 106-113.

Grabe, W., \& Stoller, L. F. (2002). Teaching and researching reading. Harlow: Pearson.

Gu, P. Y. (2003). Fine Brush and Freehand1: The Vocabulary-Learning Art of Two Successful Chinese EFL Learners. TESOL Quarterly, 37(1), 73-104.

Haladyna, T. M., Downing, S. M., \& Rodriguez, M. C. (2002). A review of multiplechoice item- writing guidelines for classroom assessment. Applied measurement in education, 15(3), 309-333.

Hassan, F., \& Selamat, N. F. (2002). Why aren't students proficient in ESL: The teachers' perspective. The English Teacher, 18-29.

Jalleh, S. (2012, September 26). Majority of teachers not proficient in English. The Star. Retrieved from http://thestar.com.my/news/story.asp?file=/2012/9/26/nation/12083360 $\&$ sec=nation

Lapp, D., Flood, J., Brock, C. H., \& Fisher, D. (2013). Teaching reading to every child. London: Routledge.

Ministry of Education Malaysia. (2011). Malaysian English Language Curriculum for Malaysian Primary Schools: A teacher's guidebook, 2011. Retrieved from http://goo.gl/Dvt3FM

Ministry of Education New Zealand. (2007). Reading comprehension strategies (Senior Primary). Retrieved from http://goo.gl/zAWwhE

Merrill, M. D. (2002). A pebble-in-the-pond model for instructional design. Performance Improvement, 41(7), 39-44

Musa, B. (2003). An education system worthy of Malaysia. Bloomington, IN: iUniverse.

Nakamoto, J., Lindsey, K. A., \& Manis, F. R. (2008). A cross-linguistic investigation of English language learners' reading comprehension in English and Spanish. Scientific Studies of Reading, 12(4), 351-371.

Nambiar, R. M. (2007). Enhancing academic literacy among tertiary learners: A Malaysian experience. 3L; Language, Linguistics and Literature, The Southeast Asian Journal of English Language Studies, 13, 77-94

Nunan, D. (2003). The Impact of English as a Global Language on Educational Policies and Practices in the Asia-Pacific Region. TESOL Quarterly, 37(4), 589-613

Nuttall, C. (2005). Teaching Reading Skills in a Foreign Language: London: MacMillan. Orasanu, J., \& Penney, M. (1986). Introduction: Comprehension theory and how it grew. Reading comprehension: From research to practice, 1-10.

O'Reilly, T., Sinclair, G., \& McNamara, D. S. (2004). iSTART: A web-based reading strategy intervention that improves students's science comprehension. In CELDA,173180. 
Ortega, L. (2009). Second language acquisition: London: Hodder education.

Paulston, C. B. \& Bruder, M. N. (1976). Teaching English as a second language: techniques and procedures. Englewood Cliffs, NJ: Prentice-Hall, Inc.

Pawanchik, S. (2006 June). Improving students' proficiency in English. Paper presented at The 2006 European College Teachmg \& Learnmg Conference, Florence, Italy. Retrieved from http://goo.gl/Ny7DrT

Pearson, P. D., \& Gallagher, M. C. (1983). The instruction of reading comprehension. Contemporary educational psychology, 8(3), 317-344.

Robberecht, R. (2007). Interactive Nonlinear Learning Environments. The Electronic Journal of e- Learning, 5(1), $59-68$.

Segawa, N. (2007). Malaysia's 1996 Education Act: The Impact of a Multiculturalismtype Approach on National Integration. SOJOURN: Journal of Social Issues in Southeast Asia, 22(1), 30-56.

Sheikh-Ahmad, I. (1997). Reading comprehension processes and strategies in L1 and L2 in Malaysian primary and secondary schools (Doctoral dissertation, University of Nottingham).

Spache, G. (1953). A new readability formula for primary-grade reading materials. The Elementary School Journal, 410-413.

Thang, S. M., \& Kumarasamy, P. (2006). Malaysian students 'perceptions of the environment contents in their English language classes. Electronic Journal of Foreign Language Teaching, 3(2), 190-208.

Virginia Department of Education, United States of America (2008). Middle school reading modules in support of project graduation. Retrieved from http://goo.gl/yUnMp1

\section{Turkish Abstract}

İkinci Dil Olarak İngilizce Öğrenen Malezyalı Ortaokul Öğrencilerinin Okuduğunu Anlamalarını Geliştirmek İçin Okuduğunu Anlama Modülleri Geliştirme

$\mathrm{Bu}$ çalışma öğrencilerin farklı okuduğunu anlama becerilerinin geliştirilmesi için 6 Okuduğunu Anlama Modülü seti geliştirmeyi amaçlamaktadır. Seti geliştirmek için farklı beceri kategorileri seçilmiştir. Makalede farklı okuma becerileri ve seviyeleri olan öğrenciler için otantik kaynaklardan değişen uzunlukta farklı metinlerin neden ve nasıl seçildiğini açıklamaktadır. Aynı zamanda gerçek anlamlı, yeniden oluşturucu ve çıkarımcı soruların seçilen metinlere göre nasıl oluşturulduğu da bu çalışmada anlatılmıştır. 5 dil uzmanı modüllerin geçerli olduğunu belirtirken, 80 öğrenciyle yapılan pilot çalışma da modüllerin güvenirliğini belirlemede kullanılmıştır. Pilot çalışmanın sonuçları katılımcıların puanlarını giderek artırdığını göstermiştir. İçsel tutarlığını belirlemek için Kuder and Richardson Formula 20 (KR-20) kullanılmıştır. Elde edilen sonuçlar 0.804 ve 0.923 arasında değerler alarak yüksek güvenirlik katsayısı göstermiştir. Modül seti titiz bir geliştirme süreciyle Pond Modeli Pebble kullanılarak standardize edilmiştir (Merril, 2002). Sonuç olarak standardize edilmiş modül seti İngilizce öğretmenleri için öğrencilerinin okuduğunu anlamada performanslarını artırmakta önemli bir konuma geleceği beklenmektedir.

Anahtar Kelimeler: okuduğunu anlama, anlama soruları, İngilizce(ESL) öğretmenleri, İngilizce (ESL) öğrenenler, artırma, OAM 


\section{French Abstract}

Développement de Lecture de Modules de Compréhension pour Faciliter Compréhension Lisante parmi Collège d'enseignement général malais ESL Étudiants

L'étude a pour but de développer un ensemble de 6 Modules de Compréhension Lisants (RCMs) pour des professeurs ESL malais pour faciliter les capacités de lecture différentes d'étudiants ESL effectivement. Des catégories de compétence différentes ont été choisies pour développer le RCMS. Cet article décrit comment et pourquoi les textes divers de longueur variante ont été adoptés et adaptés de sources authentiques diverses d'étudiants ESL ayant la lecture différente bilities/bands. Il discute aussi comment le littéral, la réorganisation et des questions déductives ont été construits convenablement basé sur les textes choisis dans le RCMs. Cinq contenu expérimenté / les experts de langue ont validé le RCMs tandis que quatre-vingts étudiants d'ESL choisis par l'échantillonnage résolu d'un collège d'enseignement général de Penang, la Malaisie a participé à l'étude pilote pour déterminer la fiabilité du RCMs. Les résultats de l'étude pilote ont révélé que les participants ont amélioré leur grand nombre progressivement. Kuder et la Formule Richardson 20 (KR-20) a été employé pour déterminer la cohérence(consistance) interne de RCMS. Les valeurs calculées de RCMS se sont étendues entre 0.804 et 0.923 qui indique la haute fiabilité. Le RCMS a été normalisé(standardisé) par un processus lié au développement rigoureux en utilisant le Caillou dans le Modèle d'Étang (Merril, 2002). Nous espérons que RCMS standardisé agirait comme des indicateurs pour les professeurs ESL pour améliorer la performance des étudiants ESL dans la compréhension lisante.

Mots Clés: en Lisant la compréhension, les questions de compréhension, ESL des professeurs, ESL des étudiants, facilitent, RCMs

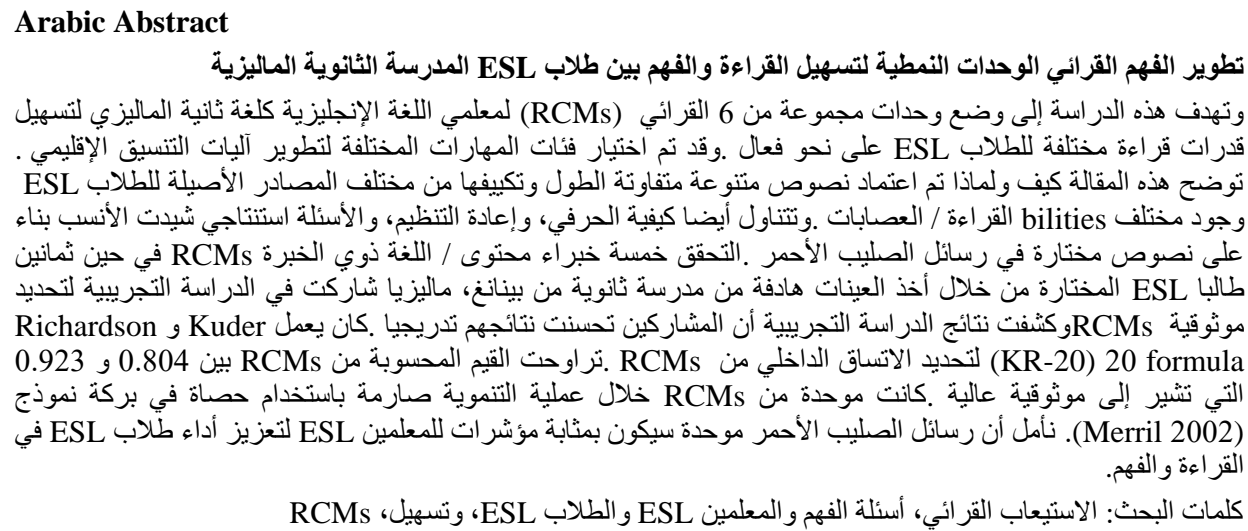

